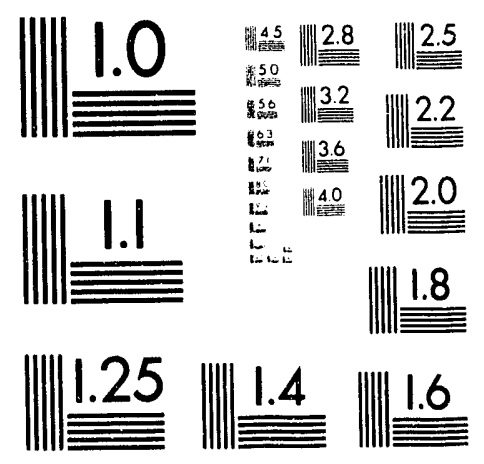



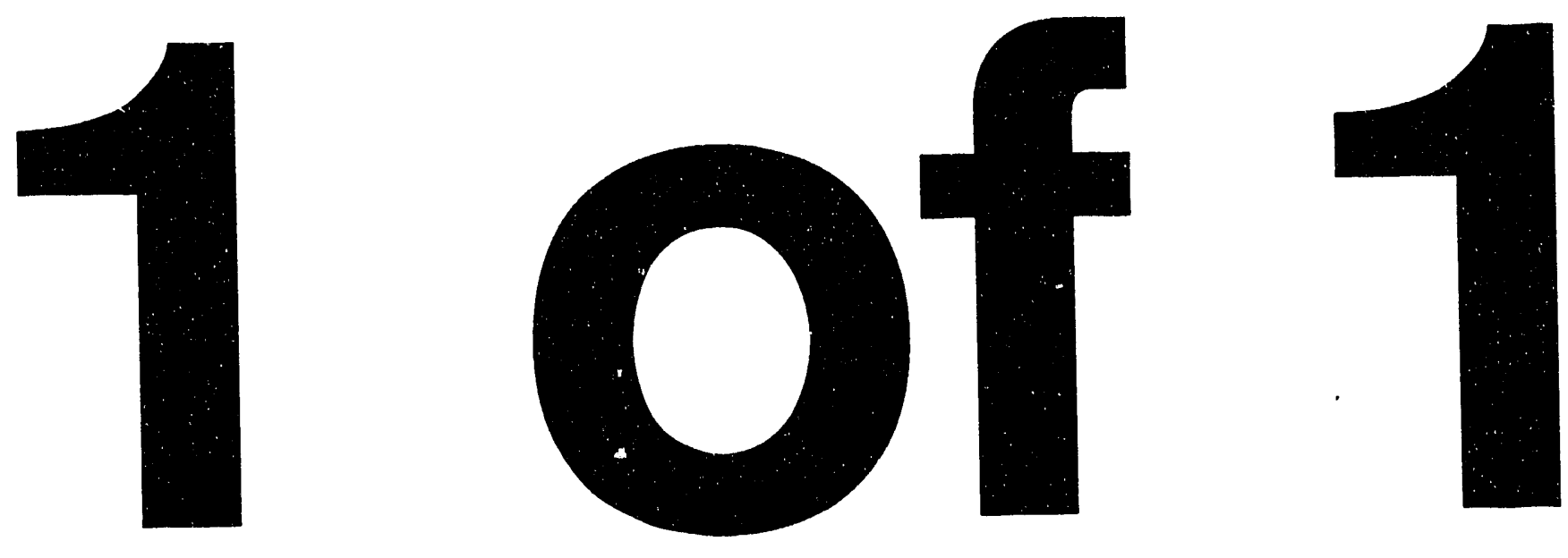


\title{
SELECTIVE TRANSFORMATION OF CARBONYL LIGANDS TO ORGANIC MOLECULES
}

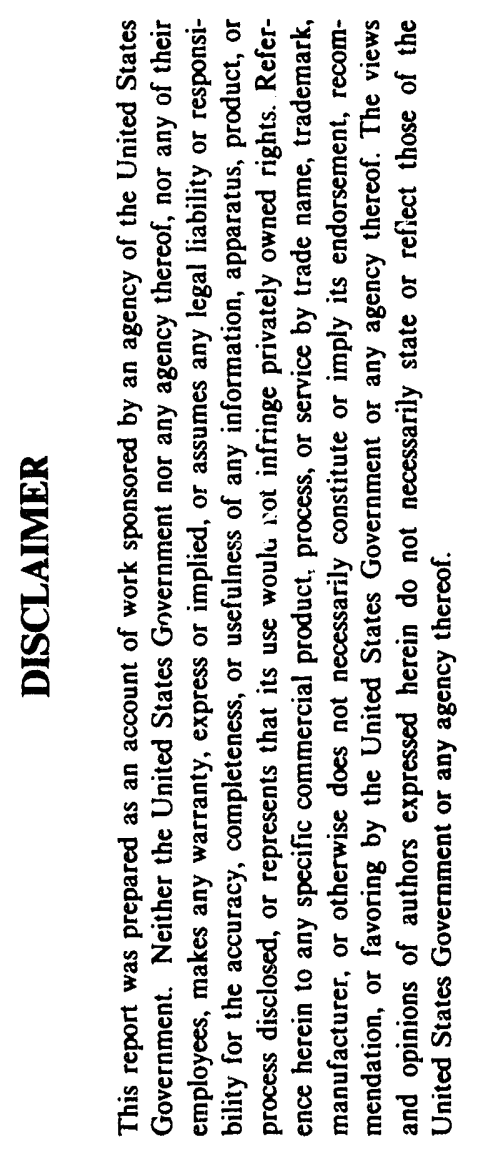

\author{
Progress Report \\ for Period $11 / 15 / 92$ - 11/14/93 \\ Principal Investigator \\ Alan R. Culler \\ Protessor of Chemistry \\ Rensselaer Polytechnic Institute \\ Troy, New York 12180-3590
}

August 10, 1993

Prepared for

The U.S. Department of Energy

Agreement No. DE-FG02-86ER 13617

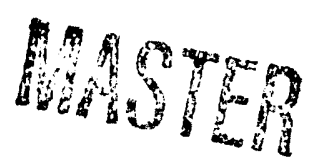


Selective Transformation of Carbonyl Ligands to Organic Molecules

Outline

PROGRESS REPORT (11/15/92-11/14/93)

Abstract (Fiscal Year 1993) 1

Selective Transformation of Carbonyl Ligands to Organic Molecules 2

A. Manganese Acyls as Hydrcsilation Substrates / Precatalysts 2

1. SiH/SiD Exchange Kinetics Study 2

2. Hydrosilation of Manganese Acety! $(\mathrm{OC})_{5} \mathrm{MnC}(\mathrm{O}) \mathrm{CH}_{3}$ with Monohydrosilanes, an Autocataly:ic Reaction 3

3. Triethylsilane Hydrosilation of Manganese Acyls $(\mathrm{CO})_{5} \mathrm{MnC}(\mathrm{O}) \mathrm{CH}_{2} \mathrm{R}$ $\left(\mathrm{R}=\mathrm{H}, \mathrm{CH}_{3}, \mathrm{OCH}_{3}\right)$. The role of the SiloxyvinylProducts $(\mathrm{CO})_{5} \mathrm{Mn}$ -

$\left.\mathrm{C}(\mathrm{OSiE})_{3}\right)=\mathrm{CHR}$ to Double Curbonylation of $(\mathrm{CO})_{5} \mathrm{MnC}_{2} \mathrm{H}_{2} \mathrm{R}$

4. Catalytic Hydrosilation of Iron Acyls $\mathrm{Cp}(\mathrm{CO})_{2} \mathrm{FcC}(\mathrm{O}) \mathrm{R}$ using Manganese Carbonyl Catalyst Precursors ( $\mathrm{CO})_{5} \mathrm{MnY}$

5. $\mathrm{PhSiH}_{3}$ Hydrosilation of Iron and Manganese Acyls $(\mathrm{CO})_{5} \mathrm{MnC}(\mathrm{O}) \mathrm{CH}_{3}$ and $\mathrm{Cp}\left(\mathrm{L},(\mathrm{CO}) \mathrm{FcC}(\mathrm{O}) \mathrm{R}: \quad \mathrm{Rh}(\mathrm{Cl})\left(\mathrm{PPh}_{3}\right)_{3}\right.$ and $(\mathrm{CO})_{5} \cdot \mathrm{MnC}(\mathrm{O}) \mathrm{R}$ Catalysis 7

B. Manganese Carbonyl-Catalyzed Hydrosilation of Organic Compounds 8

1. Manganese Carbonyl Bromide-Catalyzed Alcoholysis of the Monohydrosilane HSiMezPh 8

2. Manganesc Acyl-Catalyzed Hydrosilation of Ketones 9

3. Manganese Acyl-Catalyzed Hydrosilation of Esters 10

C. Indenyl Ruthenium Carbonylation Chemistry 12

1. Unusually Facile Carbonylation of $\left(\eta^{5}\right.$-Indenyl)ruthenium Methyl and Methoxymethyl Complexes

2. Isomerization and Carbonylation of $\left(\eta^{5}-\right.$ Indenyl)ruthenium $\alpha$-Alkoxycthyl Complexes

3. Carbonylation Driven Isomerization of in $\eta^{3}$-Indenyliruthenium Alkyl Complexes

Time and effort cornmitment 


\section{Fiscal Year-1993 Abstract}

Carbonylation of $\alpha$-alkoxyethyl ruthenium complexes $\left(\eta^{5}\right.$-indenyl)(L)(CO)Ru$\mathrm{CH}(\mathrm{OR}) \mathrm{CH}_{3}\left[\mathrm{~L}=\mathrm{PPh}_{3}, \mathrm{PE}_{3}, \mathrm{P}(\mathrm{OMe})_{3} ; \mathrm{R}=\mathrm{Me}, \mathrm{Et}_{\mathrm{t}}\right]$ gave isomerized $\alpha$-alkoxypropionyl derivatives, ( $\eta^{5}$-Ind $)(\mathrm{L})(\mathrm{CO}) \mathrm{Ru}-\mathrm{C}(\mathrm{O}) \mathrm{CH}_{2} \mathrm{CH}_{2} \mathrm{OR}$. Treatment of $\left(\eta^{5}\right.$-Ind $)(\mathrm{CO})_{2} \mathrm{Ru}-\mathrm{CH}(\mathrm{OR}) \mathrm{CH}_{3}$ with $\mathrm{PEt}_{3}$ (room temperature) provided the same products. These $\mathrm{CO}$ insertion/isomerization studies have been extended to $\left(\eta^{5}-\operatorname{Ind}\right)(\mathrm{CO})_{2} R u-n-/ i$-propyl complexes. Obtaining the necessary alkyl complexes entailed synthesizing and characterizing $\eta^{2}$-alkene complexes. ( $\eta^{5}-$ Ind)(L) (CO) $\mathrm{Ru}\left(\eta^{2}-\mathrm{CH}_{2}=\mathrm{CHR}\right)^{+}$. Diastereoselective, $\mathrm{Mn}(\mathrm{CO})_{5} \mathrm{C}(\mathrm{O}) \mathrm{Ph}$-catalyzed hydrosilation of $\mathrm{Cp}(\mathrm{L})(\mathrm{CO}) \mathrm{Fe}-\mathrm{C}(\mathrm{O}) \mathrm{CH}_{3}\left[\mathrm{~L}=\mathrm{PPh}_{3}, \mathrm{PE} \mathrm{t}_{3}, \mathrm{P}(\mathrm{OMc})_{3}, \mathrm{P}(\mathrm{OPh})_{3}\right]$ has been established. Examples of $R R$, SS and RS, SR diastereomers of $\mathrm{Cp}(\mathrm{L})(\mathrm{CO}) \mathrm{Fe}-\mathrm{CH}(\mathrm{OY}) \mathrm{CH}_{3}\left[\mathrm{Y}=\mathrm{SiHPh}_{2}\right.$, SiHEt2, Me, Et $]$ were prepared; the alkoxyethyl complexes were obtained through alcoholysis of the siloxyethyl systems. With a variety of $\mathrm{Rh}$ catalysts. $\mathrm{Cp}(\mathrm{L})(\mathrm{CO}) \mathrm{Fe}-\mathrm{C}(\mathrm{O}) \mathrm{CH}_{3}$ and dihydrosilanes transform directly to their vinyl derivatives, $\mathrm{Cp}(\mathrm{L})(\mathrm{CO}) \mathrm{Fe}-\mathrm{CH}=\mathrm{CH}_{2}$. Rh-catalyzed $\mathrm{PhSiH}_{3}$ reduction of Fe acyl complexes efficiently affords alkyl derivatives, $\mathrm{Cp}(\mathrm{L})(\mathrm{CO}) \mathrm{FeCH}_{2} \mathrm{R}[\mathrm{R}=\mathrm{Me}$, Et, t-Bu, $\mathrm{Ph}$. This silane with Mn-catalysis (e g., $\mathrm{Mn}(\mathrm{CO})_{5} \mathrm{C}(\mathrm{O}) \mathrm{Ph}$ ) quantitatively convert esters $\mathrm{RC}(\mathrm{O}) \mathrm{OR}^{\prime}$ to ethers $\mathrm{RCH}_{2} \mathrm{OR}^{\prime}$, an unprecedented reaction. These reactions, often exothermic, can be carried out on a preparative scale with a wide range of ester substrates, including unsaturated and lactones. A kinetics study on the Min(CO)5(p-toluoyl)-catalyzed SiH/SiD

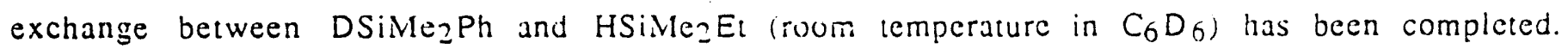
Preequilibrium kinetics were consistent with second-order isotope exchange reaction. Plots of initial velocities $u_{n}$ against (HSiMe? Et)i are consistent with saturation kinetics; Graphical analysis of double reciprocal or Lineweaver-Burk plots linear is in aceord with a ping-pong $\mathrm{Bi} \mathrm{Bi}$ mechanism that operates under rapid equilibrium eonditions and involves coordinatively unsaturated manganese silyls, $(C O)_{4} . \mathrm{Mn}-\mathrm{SiR}_{3}$. as active catalysts. These manganese silyls interconvert by sequentially adding one substrate silane and then releasing a product silane. A related mechanism apparently uperates auring MncOLBrizcatalyzed alcoholysis of HSi:Me?Ph $. v_{t}=11.200 \mathrm{n}^{-i}$ ior Z-butanol. Tertary and unsalurated alcohols $\left(1: 1\right.$ with silune) work :vith $0.01 \mathrm{~s}^{6}$ : precatalyst. 


\section{A. Manganese Acyl Complexes as Hydrosilation Substrates and Precatalysts}

Objectives:

(1) Elucidate the different pathways that are available for reactions between manganese acyl complexes $L(C O)_{4} M n C(O) R$ and hydrosilanes. Several novel ligand reactions already have been described that appear unrelaied to similar reactions involving other reductanis such as $\mathrm{H}_{2}$, metal hydrides, or stannanes?

(2) Study the reactivity of manganese alkyl, halide, and pseudohalide complexes $L(C O)_{4} M n Y$ with hydrosilanes. Many of these reactions afford extremely reactive hydrosilation catalysts. We need to understand the reactions that generate the active cotalyst(s) and optimize the catalysis.

(3) Definitively relate this hydrosilation catalysis with the reaction chemistry of coordinatively unsaturated manganese silyls $L(C O)_{3} M_{1} \cdot S_{i} R_{3}$.

\section{SiH/SiD Exchange Kinetics Study.5}

The manganese p-toluoyl complex $(\mathrm{OC})_{5} \mathrm{MnC}(\mathrm{O})-\mathrm{p}-\mathrm{C}_{6} \mathrm{H}_{4} \mathrm{CH}_{3}$ (as little as $0.5 \%$ ) catalyzes $\mathrm{SiH} / \mathrm{SiD}$ exchange between $\mathrm{DSiMc}_{2} \mathrm{Ph}\left(\mathrm{Si}^{\prime} \mathrm{D}\right)$ and $\mathrm{HSiMc}_{2} \mathrm{Et}(\mathrm{SiH})$ at room temperature in $\mathrm{C}_{6} \mathrm{D}_{6}$. This silane exchange is the simplest catalytic reaction that we can study once the excess silanes transform the precalalyst. $(O C)_{5} \mathrm{MnC}(\mathrm{O})-\mathrm{p}-\mathrm{C}_{6} \mathrm{H}_{4} \mathrm{CH}_{3}$, into the active catalyst. By doing a complete mechanistic study, we detcrmined the active catalyst and probed its reactions with hydrosilanes. This study afforded the working hypothesis for much of our current research: manganese acyl-hydrosilane mixtures ultimately generate unsaturated silyl complexes, $(\mathrm{OC})_{4} \mathrm{MnSiR} 3$, and these are plausible active catalysts for hydrosilation reactions with a variety of substrates.
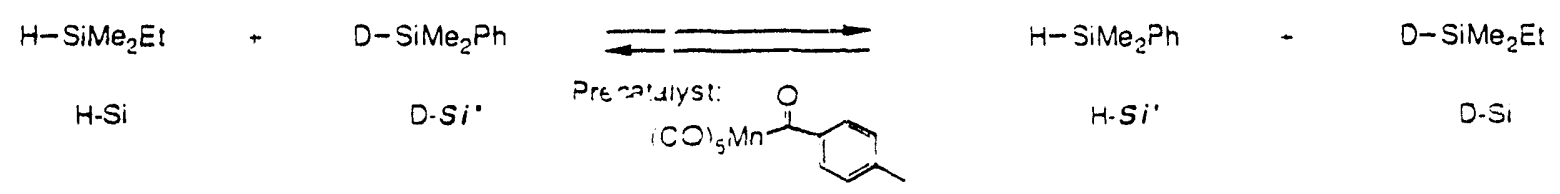

The prequilibrium kinetics of the SiH/SiD exchange are consistent with secondorder isotope exchange reaction: plots of initial velocities $U_{1}$ against (HSiMlezElli further established saturation kinetics. Lineweaver-Burk Jouble reciprocal plots of $1 / U_{1}$ vs. $1 /(\mathrm{SiH})_{i}$ are in aceord with a ping-pong Bi Bi mechanism hat operates under rapid equilibrium conditions and involves eovedinalivel: unsulurated mangunese silyts. $(O C)_{4} M n S i M e z R$, as active cataigsts. These manganese silyls interconvert by sequentially adding one substrate silane and then releasing a product silane. The torived sinetic 


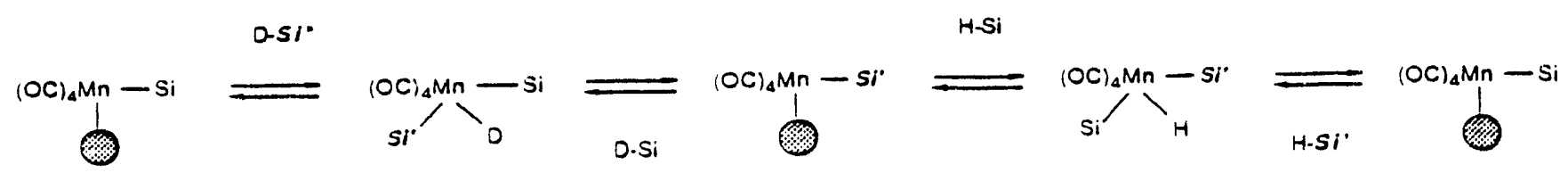

expression for this exchange reaction uniquely accounts for the appearance of these Lineweaver-Burk plots.

Although the kinetics were well behaved and reproducible, doing the appropriate controls and fitting the kinetics data to the unusua mechanism was extremely time consuming. The graphical analysis of the Lineweaver-Burk plots, however, definitively ruled out other bireactant-biproduct ( $\mathrm{Bi} \mathrm{Bi}$ ) mechanisms, including the ping-pong version under steady-state conditions that is commonly found in enzymatic systems.

During the reproducible induction period, the hydrosilanes transform the precatalyst to p-toluoyl silyl ethers (verified on a preparative scale) plus the active catalyst. Maximum catalytic efficacy for this isotope exchange required pretreating the manganese aroyl complex with excess hydrosilane for $0.75 \mathrm{~h}$ (until all starting precatalyst had been consumed) and then adding the other silane reagent. This pretreatment procedure is now our standard procedure that we use in other manganesc-catalyzed hydrosilation reactions.

2. Hydrosilation of Manganese Acetyl $(\mathrm{OC})_{5} . \mathrm{MnC}(\mathrm{O}) \mathrm{CH}_{3}$ with Monohydrosilanes, an Autocatalytic Reaction. ${ }^{7}$

Studies have been completed on the hydrosilation chemistry involving twelve monohydrosilanes and $(\mathrm{CO})_{5} \mathrm{MnC}(\mathrm{O}) \mathrm{CH}_{3}$. Of the $9 \alpha$-siloxyethyl complexes $(\mathrm{CO})_{5} \mathrm{MnCH}\left(\mathrm{OSiR}_{3}\right) \mathrm{CH}_{3}$ that formed. 7 were isolated in $46-709$ yields after column chromatography. Five then were further characterized as their stable a-siloxypropionyl derivatives (CO) $5 . \mathrm{Mn}$ -

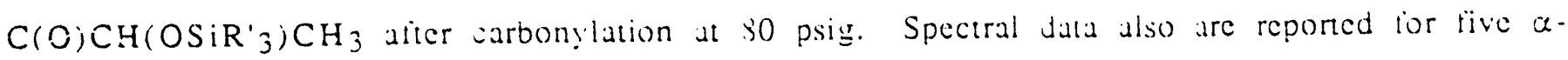
siloxyvinyl byproducts $\left(\mathrm{CO}_{5}, \mathrm{MnC} \mathrm{COS}_{\mathrm{O}} \mathrm{R}_{3}=\mathrm{CH}_{2}\right.$, their yields jepending on the silane.<smiles></smiles>

$$
\begin{aligned}
& \text { :O-: } 2 \text { eaur HSIF, O-Sifi? } \\
& \text { coisidn-idin } \\
& \text { cosin- } \\
& \text { 茫方 }
\end{aligned}
$$

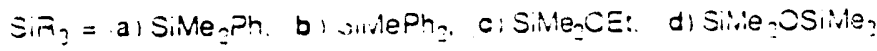

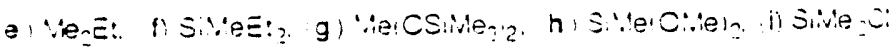


We demonstrated that these hydrosilation reactions are autosatalytic, with silaneinduced degradation of the $\alpha$-siloxyechyl complexes $(\mathrm{CO})_{5} \mathrm{MnCH}\left(\mathrm{OSiR}_{3}\right) \mathrm{CH}_{3}$ providing the coordinatively unsaturated manganese silyl $(\mathrm{CO})_{4} \mathrm{MnSiR}_{3}$ as the active catalyst. Consistent with this intermolecular process, pretreatment of catalytic quantities of $(\mathrm{CO})_{5} \mathrm{MnC}(\mathrm{O}) \mathrm{CH}_{3}$ or

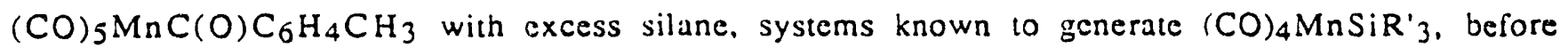
adding the substrate $(\mathrm{CO})_{5} \mathrm{MnC}(\mathrm{O}) \mathrm{CH}_{3}$ dramatically enhanced hydrosilation rates.

All observations can be accomodated by an intermolecular pathway in which the active catalyst $(\mathrm{CO})_{4} \mathrm{MnSiR}_{3}$ binds the substrate $(\mathrm{CO})_{5} \mathrm{MnC}(\mathrm{O}) \mathrm{CH}_{3}$ and rearranges to the unsaturated $\mu$-siloxyethylidene $(\mathrm{CO})_{5} \mathrm{MnC}\left(\mathrm{CH}_{3}\right)\left(\mathrm{OSiMe}_{2} \mathrm{Ph}\right) \mathrm{Mn}(\mathrm{CO})_{4}$ as the key catalysis intermediate. Silane addition then affords (CO) ${ }_{5} \mathrm{MnCH}\left(\mathrm{OSiR}_{3}\right) \mathrm{CH}_{3}$ whereas $\beta$-deinsertion

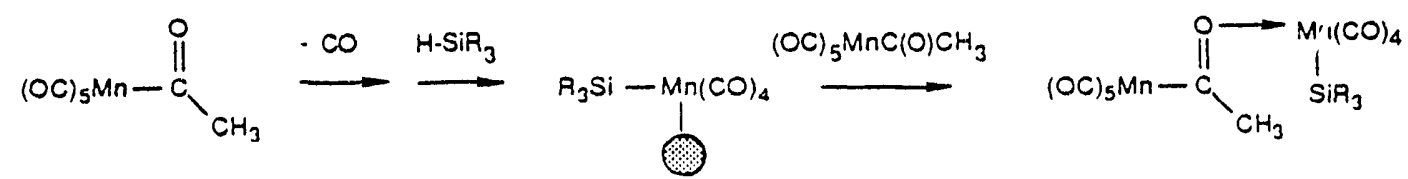

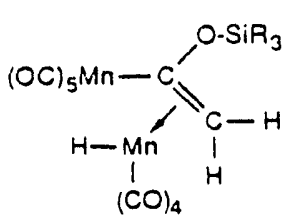<smiles>CPC1(C)CC1</smiles>

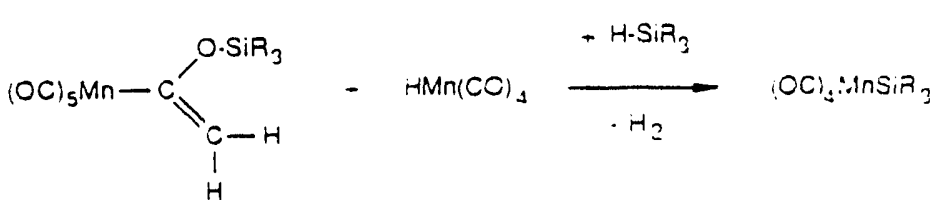

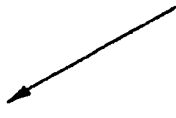

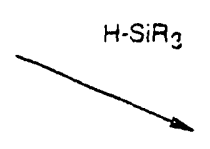
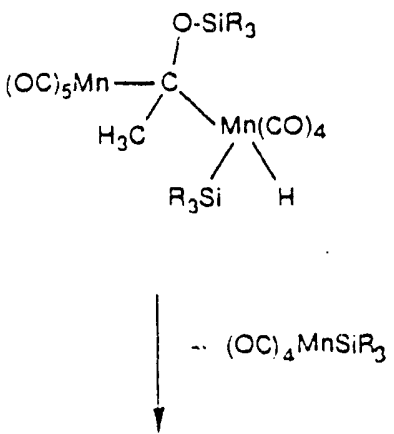

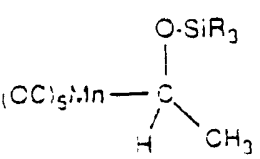

produces $(\mathrm{CO})_{5} \mathrm{MnC}\left(\mathrm{OS}_{\mathrm{R}}{ }_{3}\right)=\mathrm{CH}_{2}$. Both reactions regenerate the active aatalyst. which evidently is unstable and is replenished continuously through the silane-induced decomposition of (CO)5.MnCH(OSiR'j) $\mathrm{CH}_{3}$. We believe that this mechanisma ma be generalized iv hydrosilation reactions involving manganese acyl complexes ds precalalysts and other organometallic or organic acyl substrates. 
3. Triethylsilane Hydrosilation of Manganese Acyls $(\mathrm{CO})_{5} \mathrm{MnC}(\mathrm{O}) \mathrm{CH}_{2} \mathrm{R}(\mathrm{R}=$ $\left.\mathrm{H}, \mathrm{CH}_{3}, \mathrm{OCH}_{3}\right)$. The role of the Siloxyvinyl Products $(\mathrm{CO})_{5} \mathrm{MnC}(\mathrm{OSiEt} 3)=\mathrm{CHR}$ to Double Carbonylation of Manganese Alkyl Complexes (CO) ${ }_{5} \mathrm{MnCH}_{2} \mathrm{R} .{ }^{8}$

Of all the monohydrosilanes that we examined, triethylsilane hydrosilation of (CO) ${ }_{5} \mathrm{MnC}(\mathrm{O}) \mathrm{CH}_{3}$ afforded the greatest concentration of an $\alpha$-siloxyvinyl complex, (CO) ${ }_{5} \mathrm{MnC}\left(\mathrm{OSiE}_{13}\right)=\mathrm{CH}_{2}$, as a $2: 1$ mixture with $(\mathrm{CO})_{5} \mathrm{MnCH}\left(\mathrm{OSiE}_{13}\right) \mathrm{CH}_{3}$. The $\alpha$-siloxyvinyl complex was isolated $(55-64 \%)$ and fully characterized, but the $\alpha$-siloxycthyl compound (characterized by ${ }^{1} \mathrm{H},{ }^{13} \mathrm{C}$, and ${ }^{29} \mathrm{Si}$ NMR spectroscopy) promptly decomposed via the silaneinduced degradation under the reaction conditions. Materials balance plots for this hydrosilation reaction further indicate that both products form via independent pathways: $(\mathrm{CO})_{5} \mathrm{MnCH}\left(\mathrm{OSiE}_{3}\right) \mathrm{CH}_{3}$ does not convert to $(\mathrm{CO})_{5} \mathrm{MnC}\left(\mathrm{OSiEt}_{3}\right)=\mathrm{CH}_{2}$.

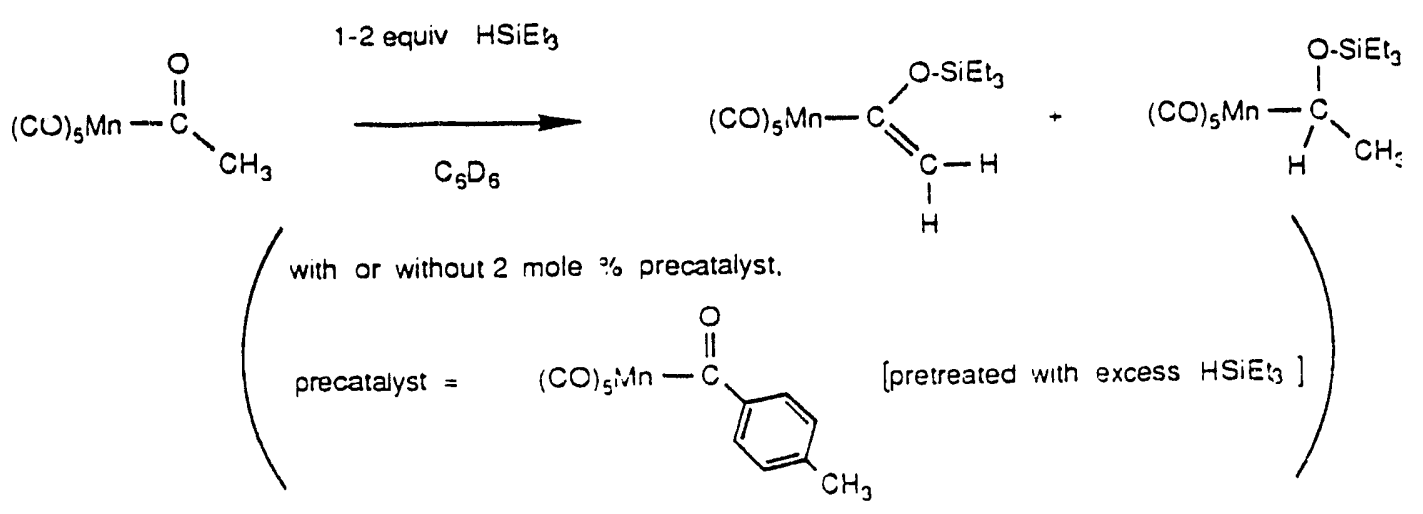

Additional mechanistic studies are consistent with the same autocatalytic hydrosilation mechanism (above) with $(\mathrm{CO})_{4} \mathrm{MnSiEt3}$ as the active catalyst. For example. pretreating catalytic quantities of the manganese toluoyl $(\mathrm{CO})_{5} . \mathrm{MnC}(\mathrm{O})-\mathrm{p}-\mathrm{C}_{6} \mathrm{H}_{4} \mathrm{CH}_{3}$ with excess HSiEt3 prior to adding the substrate $(\mathrm{CO})_{5} \mathrm{MnC}(\mathrm{O}) \mathrm{CH}_{3}$ dramatically increased the hydrosilation rates without significantly altering the product distribution.

Triethylsilane hydrosilation of $(\mathrm{CO})_{5} \mathrm{MnC}(\mathrm{O}) \mathrm{CH}_{2} \mathrm{R}\left(\mathrm{R}=\mathrm{CH}_{3}, \mathrm{OC} \mathrm{CH}_{3}\right)$ provided only the $a_{-}$ siloxyvinyl complexes $(\mathrm{Z})-(\mathrm{CO}) 5 \mathrm{MnC}\left(\mathrm{OSiE} \mathrm{L}_{3}\right)=\mathrm{CHR}$ in $55-50 \%$ isolated yields. Carbonylation of two $\alpha$-siloxyvinyl complexes gave their acyl derivatives $(E)-i C O)$ s.MnC(O)C(OSiE 13$)=C H R$ ( $>80 \%$ isolated yields): subsequent protonolysis $1 \mathrm{CF}_{3} \mathrm{CO}_{2} \mathrm{H}$ ) generated the a-kotoacyl complexes $(\mathrm{CO})_{5} \mathrm{MnC}(\mathrm{O}) \mathrm{C}(\mathrm{O}) \mathrm{CH} \geq \mathrm{R}\left(\mathrm{R}=\mathrm{H} . \mathrm{CH}_{3}\right)\left(86-899^{\circ} \mathrm{C}\right.$ after inromalograpiny). This set of ligand reactions. the net conversion of the manganese methyl and sthyl complexis to their 


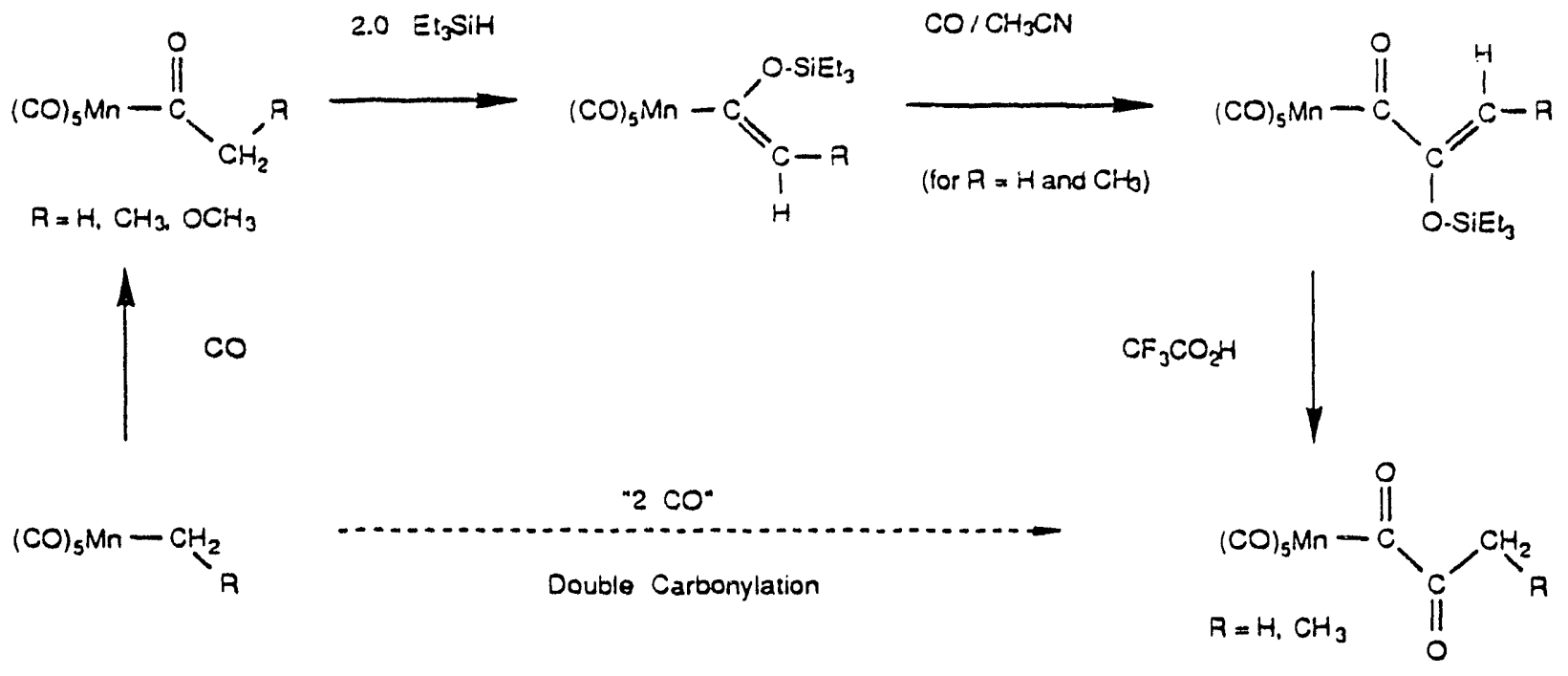

$\alpha$-ketoacyl derivatives, represents a novel double-carbonylation sequence.

4. Catalytic Hydrosilation of Iron Acyls $\mathrm{Cp}(\mathrm{CO})_{2} \mathrm{FeC}(\mathrm{O}) \mathrm{R}$ using Manganese Carbonyl Catalyst Precursors $(\mathrm{CO})_{5} \mathrm{MnY}(\mathrm{Y}=\text { Alkyl, Acyl, Halide })^{10}$

Recently completed mechanistic studies on the manganese-catalyzed hydrosilation of the iron acyls $\mathrm{Cp}(\mathrm{CO})_{2} \mathrm{FeC}(\mathrm{O}) \mathrm{CH}_{3}\left(\mathrm{FpCOCH}_{3}\right)$ and $\mathrm{FpC}(\mathrm{O}) \mathrm{Ph}$ satisified three objectives.

(1) These reactions represent the catalytic hydrosilation of nonlabile metal acyl complexes. The substrate iron acyls accordingly do not function also as catalyst precursors. and are unreactive towards hydrosilanes in the absence of a catalyst. With an appropriate catalyst, these reactions afford easily isolated and stable $\alpha$-siloxyalkyl iron complexes. FpCH(OSiR $\left.{ }_{3}\right) \mathrm{R} .\left(\mathrm{R}=\mathrm{CH}_{3}\right.$, Ph), with a varicty of mono- and dihydrosilanes.

(2) A variety of manganese complexes $\mathrm{L}(\mathrm{CO})_{4} \mathrm{MnY}$ have been tested as precatalysts.

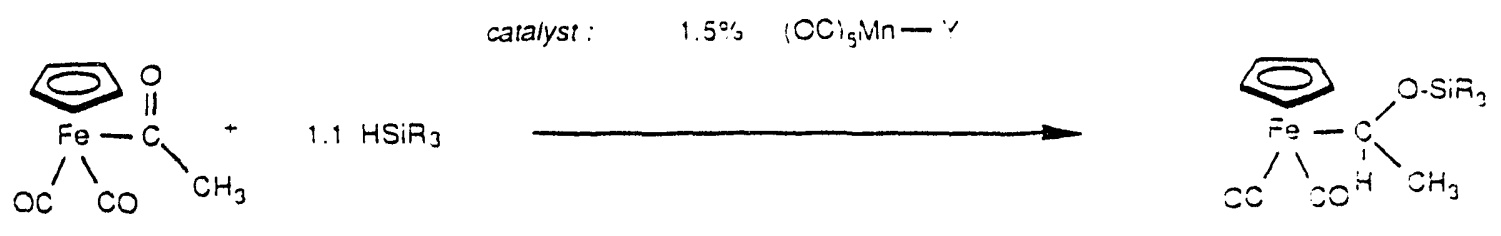

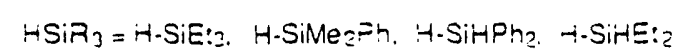

ior H.SiMe? $z^{\text {Ph }}$ :

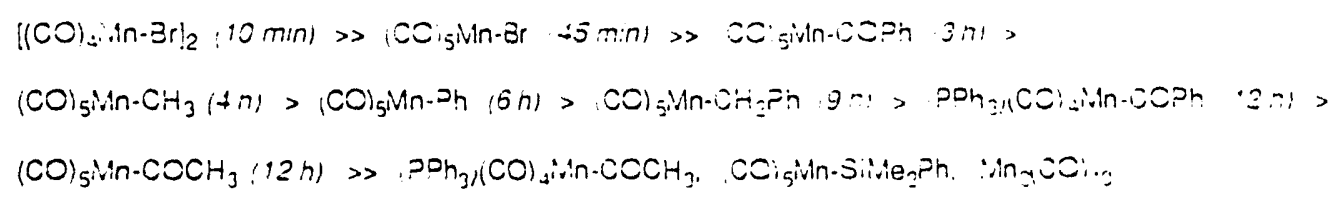


and reaction conditions have been optimized. These manganese catalytic systems typically are far more active and selective than are the rhodium catalysts that we examined.

(3) Results of mechanistic studies on using manganese acyl precatalysts (CO) $5 \mathrm{Mn}$ $\mathrm{C}(\mathrm{O}) \mathrm{R}\left(\mathrm{R}=\mathrm{CH}_{3}, \mathrm{Ph}\right)$ are consistent with our autocatalysis pathway. First these precatalysts must hydrosilate and then degrade to manganese silyl active catalysts, reactions that the iron acyl substrates competitively inhibit. Thus, the reaction time for $(\mathrm{CO})_{5} \mathrm{MnC}(\mathrm{O}) \mathrm{Ph}$ catalyzed hydrosilation ( $\mathrm{HSiMe}_{2} \mathrm{Ph}$ ) of $\mathrm{FpCOCH}_{3}$ decreases from three hours to twenty minutes when the manganese precatalyst is treated with the excess silane (45 $\mathrm{min})$ before adding the $\mathrm{FpCOCH}_{3}$ substrate.

5. PhSiH 3 Hydrosilation of Iron and Manganese Acyls $(\mathrm{CO})_{5} \mathrm{MnC}(\mathrm{O}) \mathrm{CH}_{3}$ and $\mathrm{Cp}(\mathrm{L})(\mathrm{CO}) \mathrm{FeC}(\mathrm{O}) \mathrm{R} ; \quad \mathrm{Rh}(\mathrm{Cl})\left(\mathrm{PPh}_{3}\right)_{3}$ and $(\mathrm{CO})_{5} \mathrm{MinC}(\mathrm{O}) \mathrm{R}$ Catalysis. ${ }^{2}$

By using the more reactive phenylsilane, we catalytically hydrosilated and reduced organometallic acyls. The products of these reactions depended on whether $\mathrm{Rh}\left(\mathrm{Cl}_{1}\right)\left(\mathrm{PPh}_{3}\right)_{3}$ or $(\mathrm{CO})_{5} \mathrm{MnC}(\mathrm{O}) \mathrm{R}\left(\mathrm{R}=\mathrm{CH}_{3}, \mathrm{Ph}\right)$ wis used as a catalyst, an unusual development. With other hydrosilanes, these manganese acyls are much more reactive hydrosilation catalysts than Wilkinson's compound, although both types typically provided the same products.

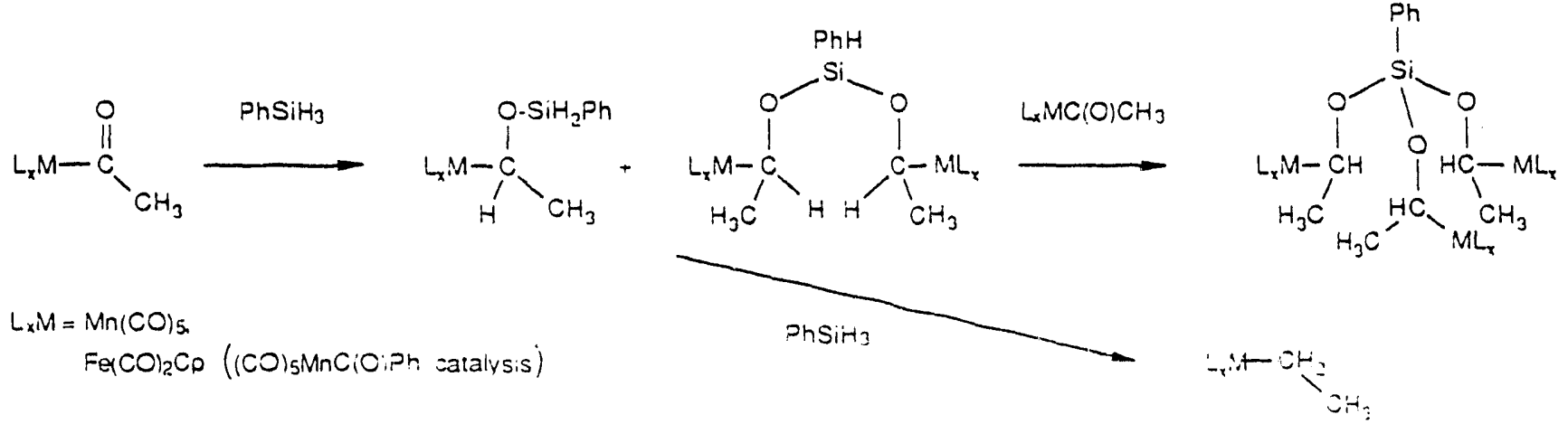

With the manganese acyl precatalysts. PhSiHz and $\mathrm{FpClO} / \mathrm{CH}_{3}$ transformed to the depicted mono-, bis-. and tris-a-siloxyethyl complexes. The mono-iron and bis-iron adducts formed first, then they competitiveiy transtormed into the tris-iron compound and the fully reduced iron ethyl complex. $\mathrm{FPCH}_{2} \mathrm{CH}_{3}$. Altor :2 hours, only the lutter inmonounds remained. The fully characterized tris-iron compound did not convert amo FPCH:CH: uncer the original reaction conditions. Essentially the sume reditions tranpired upon treating 
(CO) ${ }_{5} \mathrm{MnC}(\mathrm{O}) \mathrm{CH}_{3}$, the substratc, with $\mathrm{PhSiH}_{3}$.

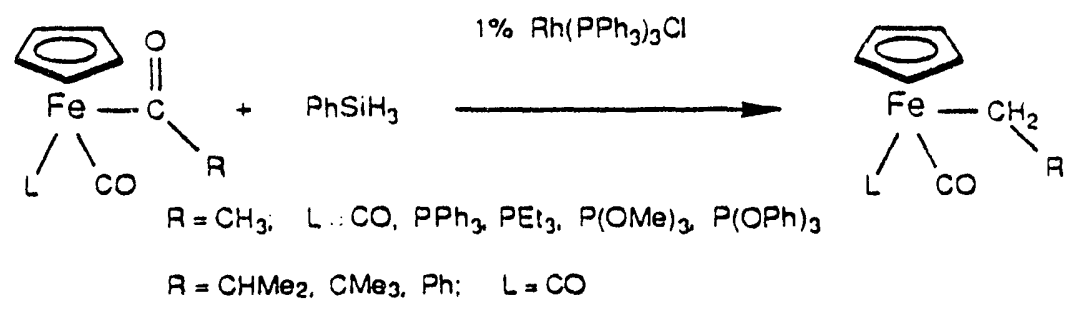

$\mathrm{Rh}(\mathrm{Cl})\left(\mathrm{PPh}_{3}\right)_{3}$ also catalyzes phenylsilane hydrosilation of $\mathrm{FpC}(\mathrm{O}) \mathrm{CH}_{3}$ and the other CpFe acyl complexes depicted. These reactions produced only their fully reduced alkyl derivatives, with no detectable intermediates. The $65-90 \%$ isolated yields of the indicated iron alkyl complexes categorizes this $\mathrm{Rh}(\mathrm{Cl})\left(\mathrm{PPh}_{3}\right)_{3}$-catalyzed phenylsilane hydrosilation as a useful synthetic method for reducing (iron) acyl complexes.

\section{B. Manganese Carbonyl-Catalyzed Hydrosilation of Organic Compounds}

\section{General Observations:}

(1) Manganese complexes, particularly $(\mathrm{CO})_{5} \mathrm{MnBr},(\mathrm{CO})_{5} \mathrm{MnC}(\mathrm{O}) \mathrm{Ph}$, and $\mathrm{PPh}_{3}(\mathrm{CO})_{4} \mathrm{Mn}$ $\mathrm{C}(\mathrm{O}) \mathrm{CH}_{3}$, selectively catalyze a variety of reactions between hydrosilanes and $\mathrm{C}-\mathrm{O}$ bonds on organic molecules. Carbon-carbon double bonds are unreactive.

(2) The manganese catalysts usilally are much more reactive. than $\mathrm{RhCl}\left(\mathrm{PPh} \mathrm{h}_{3}\right.$ and even ccialyze a number of reactions that RhCl(PP/:3/3 will not.

(3) During these hydrosilation reactions most of the manganese precatalyst (typically added at 1-5\%) is unaltered. at least until the substrate gets consumed. Pretreatment of a manganese acyl with the excess silane (until the former is consumed) before adding the substrate rapidly generates tiie active catalyst and subsequently accelerates the catalysis. Timing this pretreatment procedure is difficult since the active catalyst has a limited lifetime.

1. Manganese Carbonyl Bromide-Catalyzed Aleoholysis of the Monohydrosilane HSillezPh.6

Dimeric manganese carbonyl bromide $[$ Mn $\mathrm{CO} / 4 \mathrm{Br} / 2$ is extremely effective at catalyzing the alcoholysis of dimethylphenylsilane in benzene at room lemperature. Preparative scale procedures using 1200: 1200: I mixtures al alcohol. HSillezPh. and $[\mathrm{Mn}(\mathrm{CO})+\mathrm{Br}]_{2}$ (0.084 mol or athorded analytically pure alkoxysilanes in good yelds. 1 .

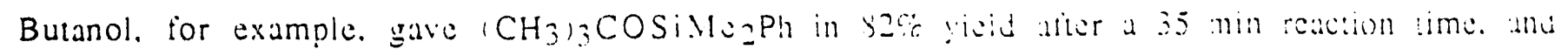


allyl and propargyl alcohols quantitatively transformed to their alkoxysilane derivitives. with no evidence of competing hydrosilation of the carbon-carbon multiple bonds.

Competitive reactions involving $1: 1: 1$ mixtures of sec-butanol-acctone-HSiMe ${ }_{2} \mathrm{Ph}$ and $\left[\mathrm{Mn}(\mathrm{CO})_{4} \mathrm{Br}\right]_{2}$ as catalyst exhibited chemoselective alcoholysis of dimethylphenylsilane.

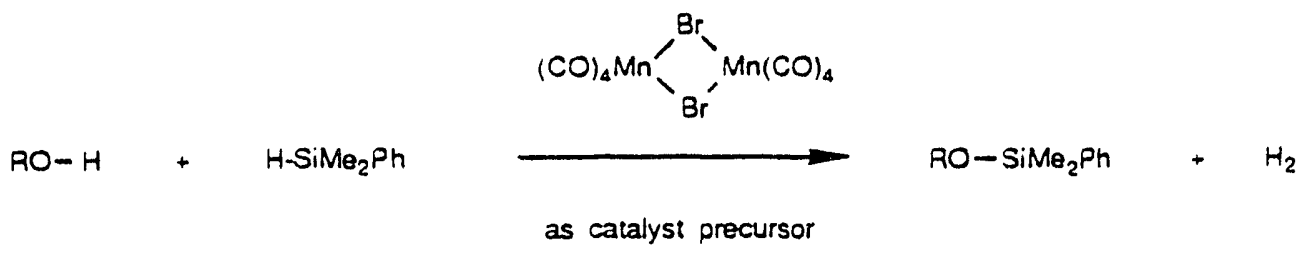

${ }^{1} \mathrm{H}$ NMR spectral monitoring of catalyzed reactions between methanol or sec-butanol with HSiMe $2 \mathrm{Ph}$ was used in screening other manganese carbonyl complexes as potential HSiMe ${ }_{2} \mathrm{Ph}$ alcoholysis catalysts. Their reaction times varied: $\left[\mathrm{Mn}(\mathrm{CO})_{4} \mathrm{Br}\right]_{2}>\mathrm{Mn}(\mathrm{CO})_{5} \mathrm{Br}>>$ $\mathrm{Mn}(\mathrm{CO})_{5} \mathrm{CH}_{3}=\mathrm{Mn}(\mathrm{CO})_{5} \mathrm{C}(\mathrm{O}) \mathrm{Ph}>\mathrm{Mn}\left(\mathrm{PPh}_{3}\right)(\mathrm{CO})_{4} \mathrm{Br}>\mathrm{Mn}\left(\mathrm{PPh}_{3}\right)(\mathrm{CO})_{4} \mathrm{C}(\mathrm{O}) \mathrm{CH}_{3}>>$ $\mathrm{Mn}(\mathrm{CO})_{5}\left(\mathrm{SiMe}_{2} \mathrm{Ph}\right) \gg \mathrm{Mn}_{2}(\mathrm{CO})_{10} \approx \mathrm{Rh}\left(\mathrm{PPh}_{3}\right)_{3} \mathrm{Cl}$ (no reaction).

Solvent-dependent turnover frequencies were detcrmined for the $\left[\mathrm{Mn}(\mathrm{CO})_{4} \mathrm{Br}\right]_{2}(1.4$ mol \%) -catalyzed dehydrocoupling of sec-butanol and HSiMc $2 \mathrm{Ph}(0.289 \mathrm{M}): \quad N_{t}=2183$ (THF), $2728\left(\mathrm{C}_{6} \mathrm{H}_{6}\right)$, and $5457 \mathrm{~h}^{-1}\left(\mathrm{CH}_{2} \mathrm{Cl}_{2}\right)$. In a second procedure, a preparative scale reaction (3.12 $\mathrm{M}$ for each reactant) in $\mathrm{CH}_{2} \mathrm{Cl}_{2}$ containing only $0.08+$ mol \% precatalyst afforded a much higher turnover frequency of $11.217 \mathrm{~h}^{-1}$.

2. Manganese Acyl-Cata!yzed Hydrosilation of Ketones. Work in progress: $\mathbf{M}$. DiBiase and B. T. Gregg

The manganese acetyl $\mathrm{PPh}_{3}(\mathrm{CO})_{4} \mathrm{MnC}(\mathrm{O}) \mathrm{CH}_{3}$ is an extremely elfective precatalyst for hydrosilating the kriones in the accompanying thart. (Reaction times were determined by 'H NMR spectral monitoring under conparable conditions.) Interestingly. RhCi(PPhz)3 does not catalyze inydrosilation reactions involving the monohydrosilane. With diphenylsilane, the manganese and rhodium exhibit similar activities. Pectratment of $\mathrm{PPh}_{3}(\mathrm{CO})_{4} \mathrm{MnC}(\mathrm{O}) \mathrm{CH}_{3}$ with the silane 20 min prior 10 adding the ketone jramatieally enhances the hydrosilation rale.

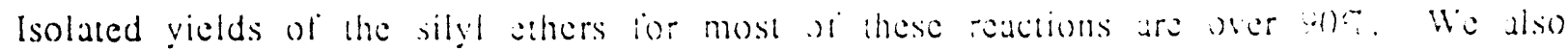



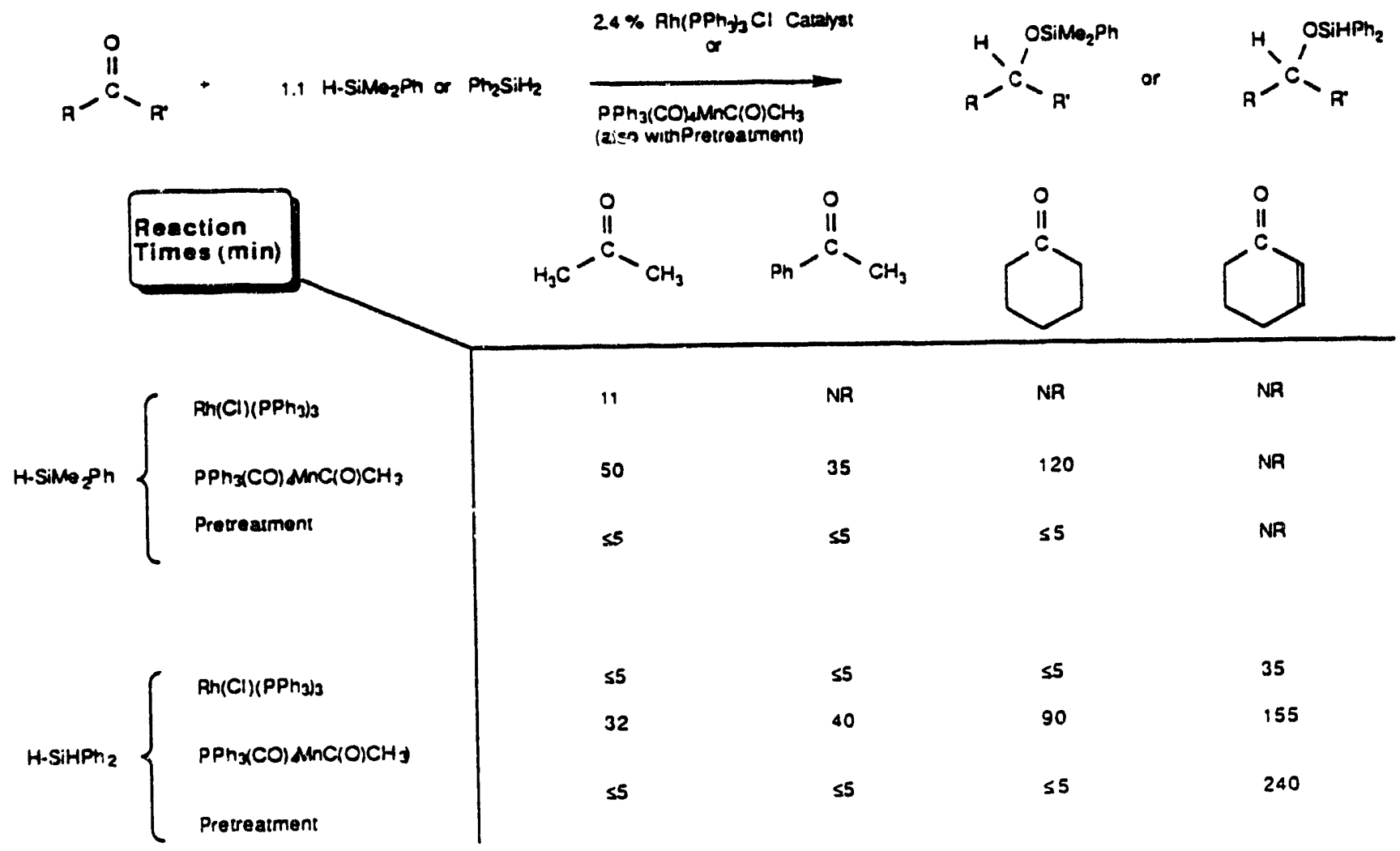

noted that $\mathrm{PPh}_{3}(\mathrm{CO})_{4} \mathrm{MnC}(\mathrm{O}) \mathrm{CH}_{3}$ is a much more active ketone hydrosilation catalyst than $(\mathrm{CO})_{5} \mathrm{MnC}(\mathrm{O}) \mathrm{CH}_{3},(\mathrm{CO})_{5} \mathrm{MnC}(\mathrm{O}) \mathrm{C}_{6} \mathrm{H}_{4} \mathrm{CH}_{3}$ (even with pretreatment), (CO) ${ }_{5} \mathrm{MnBr}$, and others. Work remaining entails accurately measuring some turnover frequencies in order to quantify the unusually high catalyst activity.

3. Manganese Acyl-Catalyzed Hydrosilation of Esters. Work in progress: $Z$. Mao and B. T. Gregg

Last year. we announced that several manganese complexes catalytically reduce organic esters with hydrosilunes. Thus $\mathrm{PhSi}_{3}$ and $\leq 2 \% \mathrm{PPh}_{3}(\mathrm{CO})_{4} \mathrm{HnC}(\mathrm{O}) \mathrm{CH}_{3}$, the most effective precatalyst. quantitative!y reduce a number of esters to their ethers. These exothermic reactions are complete in $<+5 \mathrm{~min}$, with no other organic products detected by ${ }^{1} \mathrm{H}$ and ${ }^{13} \mathrm{C}$ NMR spectroscopy.

Other esters upon satalytic PhSiH: hydrosilation give mixtures of silyt acetals and the fully reduced ethers isee abovel. Varying the ester. precatalyst. and other reaction conditions alters the proportion of silyt acetal. which forms ds mono-. bis-. and tris-silyi 


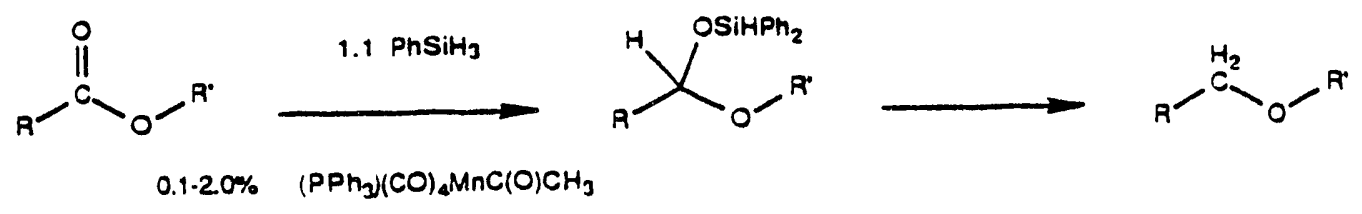

\section{Results}
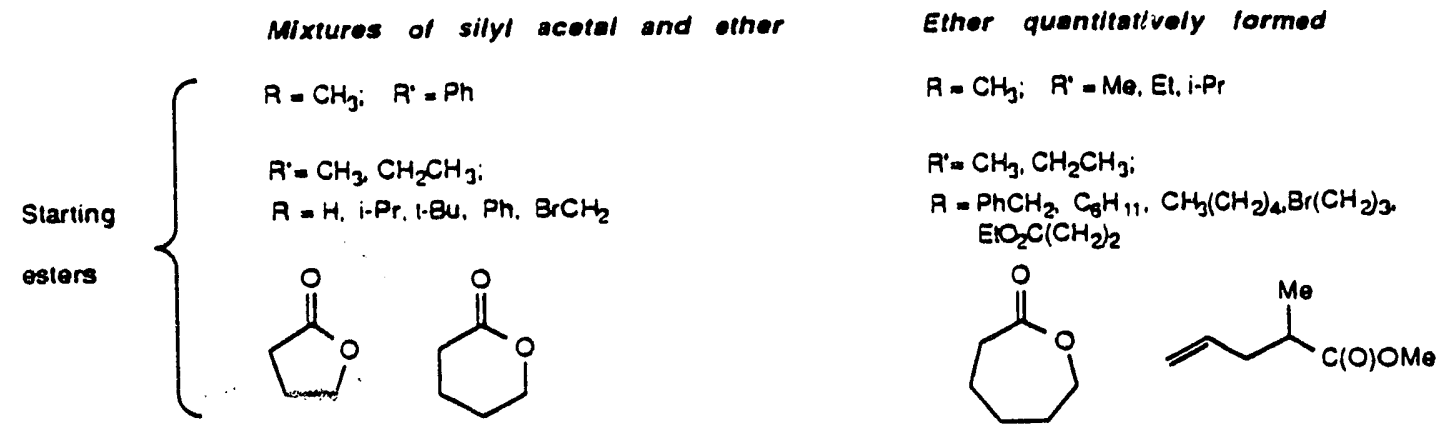

Currently under study

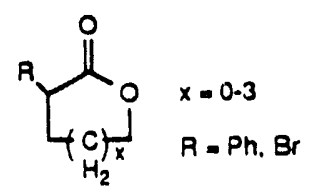<smiles>O=C1CCc2ccccc2O1</smiles><smiles>[R]C=CC(C)(C)O</smiles><smiles>[R]C=COC(C)C(C)=O</smiles>

acetal adducts of $\mathrm{PhSiH}_{3}, \mathrm{PhSiH}_{n}\left[O C H R\left(O R^{\prime}\right)\right]_{3-n}$. Fortunately, several analogous mono- and bis-silyl acetal adducts of $\mathrm{Ph}_{2} \mathrm{SiH}_{2}, \mathrm{Ph}_{2} \mathrm{SiH}_{n}\left[\mathrm{OCHR}(\mathrm{OR})_{2-n}\right.$ (fully characterized), serve as spectroscopic models for their $\mathrm{PhSiH}_{3}$ andogs. These $\mathrm{Ph}_{2} \mathrm{SiH}_{2}$-derived silyl acetals are the sole products our manganese-catalyzed ester hydrosilation reactions.

Very little precedent exists for directly reducing esters to chers! This hydrosilation represents an extremely efficient homogeneous catalytic procedure for carrying out an otherwise difficult organic reduction. Remaining work on our ester reduction centers on understanding the precatalyst / $\mathrm{PhSiH}_{3}$ / active catalyst chemistry and includes:

(1) Optimizing the reacion conditions for converting esters to ethers and the purification procedures for separating the ether products from contaminating silyl acetals.

(2) Selectively reducing esters 10 silyl acelals with $\mathrm{Ph}_{2} \mathrm{SiH}_{2}$ represents a potentially convenient synthesis of aldehydes (atier hydrolysis of the sily! acetals).

(3) Extending the synthatic scope of ester hydrosilation to earboxylit acid anhydrides. amides/lactams, and perhaps aven CO= may be possible.

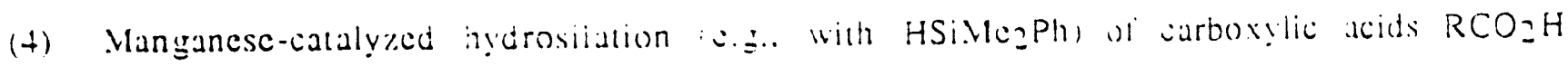


quickly and quantitatively gives silyl esters, $\mathrm{RCO}_{2} \mathrm{SiR}_{3}$. Their further catalytic hydrosilation with $\mathrm{PhSiH}_{3}$ will be examined.

(5) Silane. $\mathrm{SiH}_{4}$, should be an even more potent reductant in these catalytic hydrosilations.

\section{Indenyl Ruthenium Carbonylation Chemistry}

Objectives:

(1) Indenyl ruthenium alkyl complexes $\left(\eta^{5}-C_{9} H_{7}\right)(L)(C O) R u R$ exhibit incredibly facile carbonylation reactivity. Our immediate goal is to use the "indenyl effect" to drive otherwise infeasible carbonylation reactions.

(2) Establish that reversible $\eta^{5} / \eta^{3}$ indenyl ring slippage is the driving force in the carbonylation reactions of $\left(\eta^{5}\right.$-indenyl) iron and ruthenium alkyl complexes. This reactivity engenders a novel associative pathway in organometallic chemistry.

(3) Determine if indenyl ruthenium alkyl complexes undergo alkyl ligand reactions under unusually mild conditions. Ligand reactions of interest include alkyl-alkene migratory insertion. alkyl ligand isomerization, and the reactions of hydrosilanes with the alkyl complexes.

(4) Ascertain if ruthenium hydride and silyl complexes $\left(\eta^{5}-C_{9} H>\right)(L)(C O) R u R(R=H$, $\left.S_{i R}{ }^{3}\right)$ associate and incorporate (migratory insertion) $\mathrm{CO}, \mathrm{CO}_{2}$, alkenes, and ketones.

1. Unusually Facile Carbonylation of $\left(\eta^{5}-\right.$ Indenyl)ruthenium Methyl and Methoxymethyl Complexes. ${ }^{9}$

We established the unusually mild carbonylation chemistry of $\eta^{5}$-indenyl ruthenium alkyl complexes involving the ten methyl / acetyl and methoxymcthyl / methoxyacetyl complexes depicted. The methyl-to-acetyl carbonylations take place under incredibiy mild conditions, $15-50$ psig $\mathrm{CO}$ in $\mathrm{CH}_{2} \mathrm{Cl}_{2}\left(2{ }^{\circ} \mathrm{C}\right.$ ). (Carbonylation reactions involving $\mathrm{CpRu}$ congeners require considerably more vigorous conditions. $\quad$... $100(\mathrm{a}) \mathrm{m}$ CO for $\mathrm{Cp}(\mathrm{CO})_{2} \mathrm{RuCH}_{3}$ in nitromethane.)

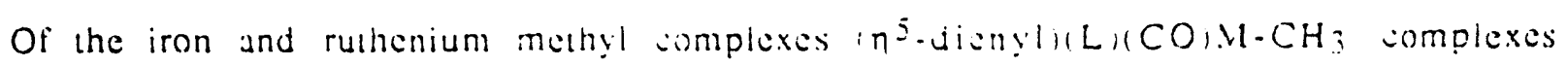
that we have studied. Ind $\left(P P h_{3}\right)\left(C O, R u C H 3\right.$ represents the mosi and $C_{p l C O} 2 R u C H 3$ the least reactive. According to our working inpothesis. coversible $\eta^{\vdots} \eta^{3}$ indengl ring ilippige couples first with association of $C O$ and then with alkyl migration to glve the produce acyl. Support for IndRu alkyl complexes associating CO icommensurate with $\eta^{5}$ in -indenyi ring 


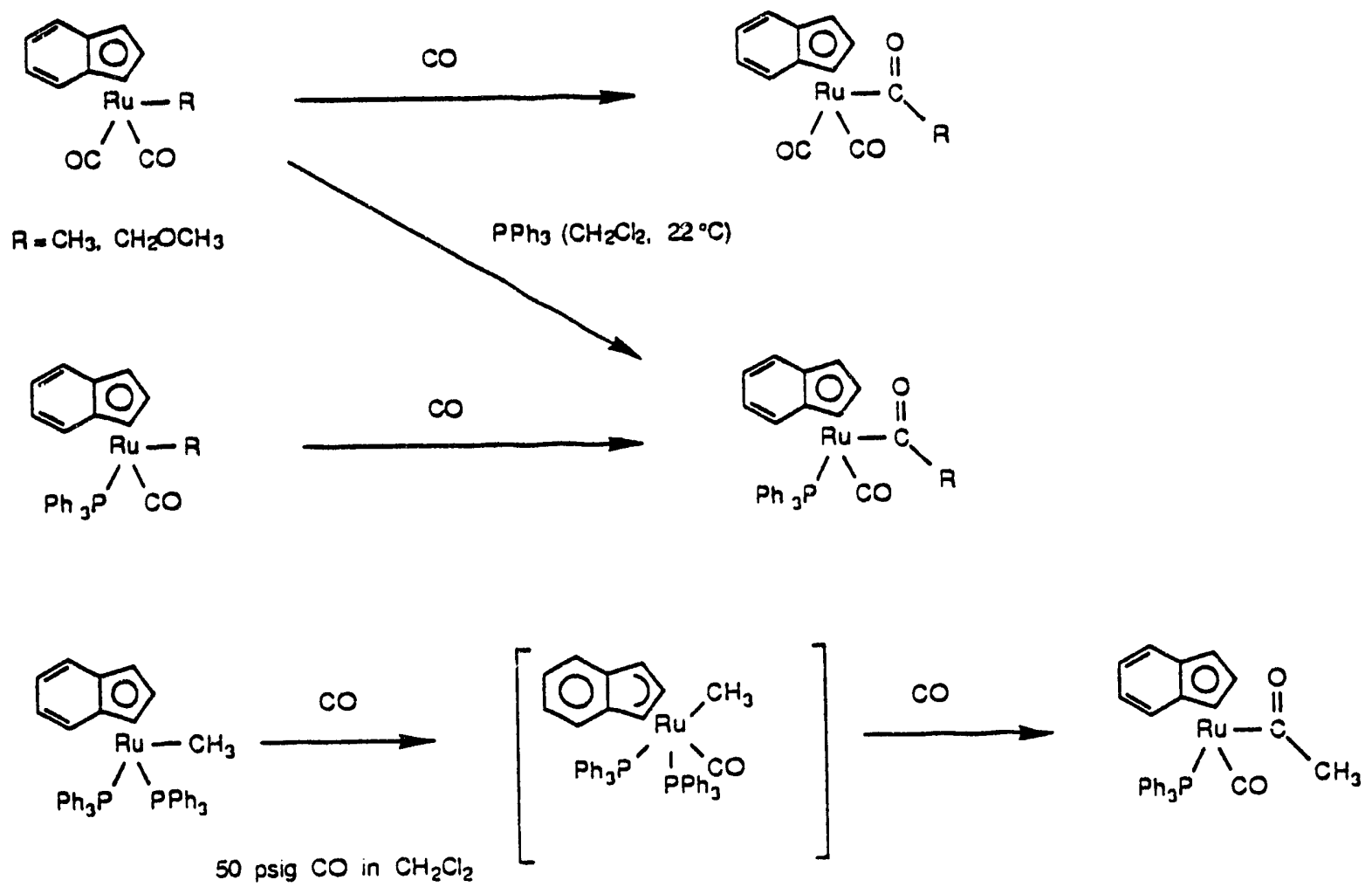

slippage) during their carbonylation reactions derives from the results of carbonylating Ind $\left(\mathrm{PPh}_{3}\right)_{2} \mathrm{RuCH}_{3}$. This complex efficiently incorporates $\mathrm{CO}\left(\leq 50 \mathrm{psig}, 22^{\circ} \mathrm{C}\right.$ in $\left.\mathrm{CH}_{2} \mathrm{Cl}_{2}\right)$ and gives an acetyl complex in which a phosphine ligand also has been replaced by $C O$. The Cp analog, $\mathrm{Cp}\left(\mathrm{PPh}_{3}\right)_{2} \mathrm{Ru}-\mathrm{CH}_{3}$, docs not interact with $\mathrm{CO}(80$ psig).

The significant result is that now we can dircclly carbonylate these $\alpha$-alkoxymethyl complexes under conditions where CpFc, IndFe, and $\mathrm{CpRu}$ congencrs are inert towards CO. Much of our present efforts are directed towards extending the unusually high carbonylation reactivity of these IndRu alkyl complexes to other ligand reactions.

2. Isomerization and Carbonglation of $(\eta$ E-Indengl)ruthenium $\alpha-A l k o x y-$ ethyl Complexes. 13

We also are in the process of publishing results on the unprecedented $\alpha$-alkoxycthyl ligand isomerization-then-carbonylation. Either treating Ind $(\mathrm{CO})=\mathrm{R} u \mathrm{CH}(\mathrm{O} . \mathrm{Ma}) \mathrm{CH} 3$ with $\mathrm{PPh}_{3}$ or carbonylating Ind(L)(CO)RuCH(OR)CH3 affords the sume 3 -alkoxypropionyl products. No intermediates were detected. These products are decounted or by iequential 3 hydrogen migratory deinsertion: reinsertion that isomerizes the alky tigand prior to 
carbonylation. The facility of this isomerization is consistent with coupling reversible $\eta^{5} / \eta^{3}$ indenyl ring slippage and the deinscrtion / reinsertion steps as illustrated.

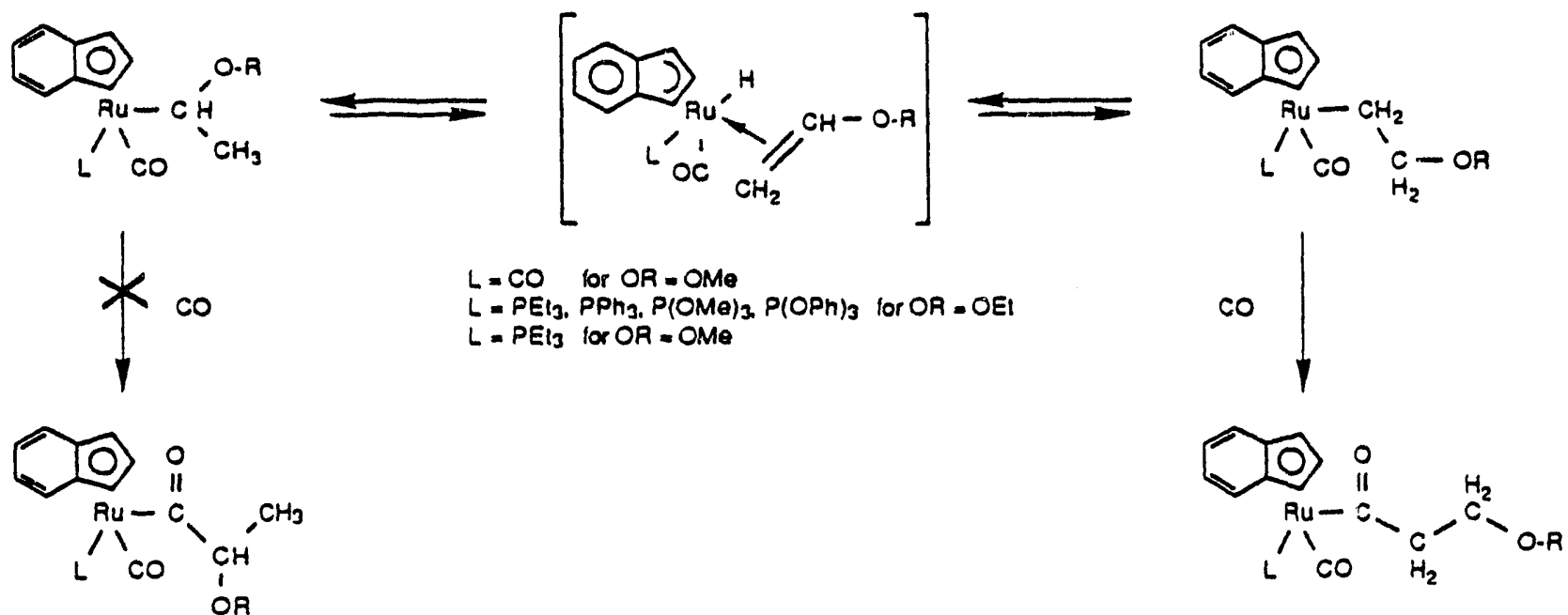

An intriguing observation on this IndRu $\alpha$-alkoxyethyl chemistry is that the carbonylation step drives the $\alpha$-alkoxyethyl ligand isomerization. The IndRu $\alpha$ alkoxyethyl complexes do not rearrange to their $\beta$-alkoxyethyl iscmers in the absence of $C O$. Presumably low concentrations of this $\beta$-alkoxyethyl isomer do form and preferentially carbonylate, thus shifting the $\alpha-/ \beta$-alkoxycthyl ligand equilibrium to the right.

\section{Carbonylation Driven Isomerization of $\left(\eta^{5}\right.$-Indenyl)ruthenium Alkyl}

Complexes. Work in progress: R. J. Chiulli

The following scheme outlines synthetic chemistry in progress concerning phosphine-promoted $\mathrm{CO}$ insertion reactions on Ind $(\mathrm{CO})_{2} \mathrm{Ru}$ alkyl complexes. Our approach entails generating mixtures of iso-and normal-alkyl ligand isomers and assess the extent of their isomerization in the absence and presence of phosphine. Thus far. we generated $45 / 55$ mixtures of the isopropyl and n-propyl complexes $i R=$.le), which on the laborator: time frame did not isomerize. Carbonylating these methylene chloride solutions. however. transformed these mixtures into a $10 / 90$ ratio of isobutyry and n-butyryl complcxes. Apparently, the alkyl ligand isomerization is linked to the carbonylation. 


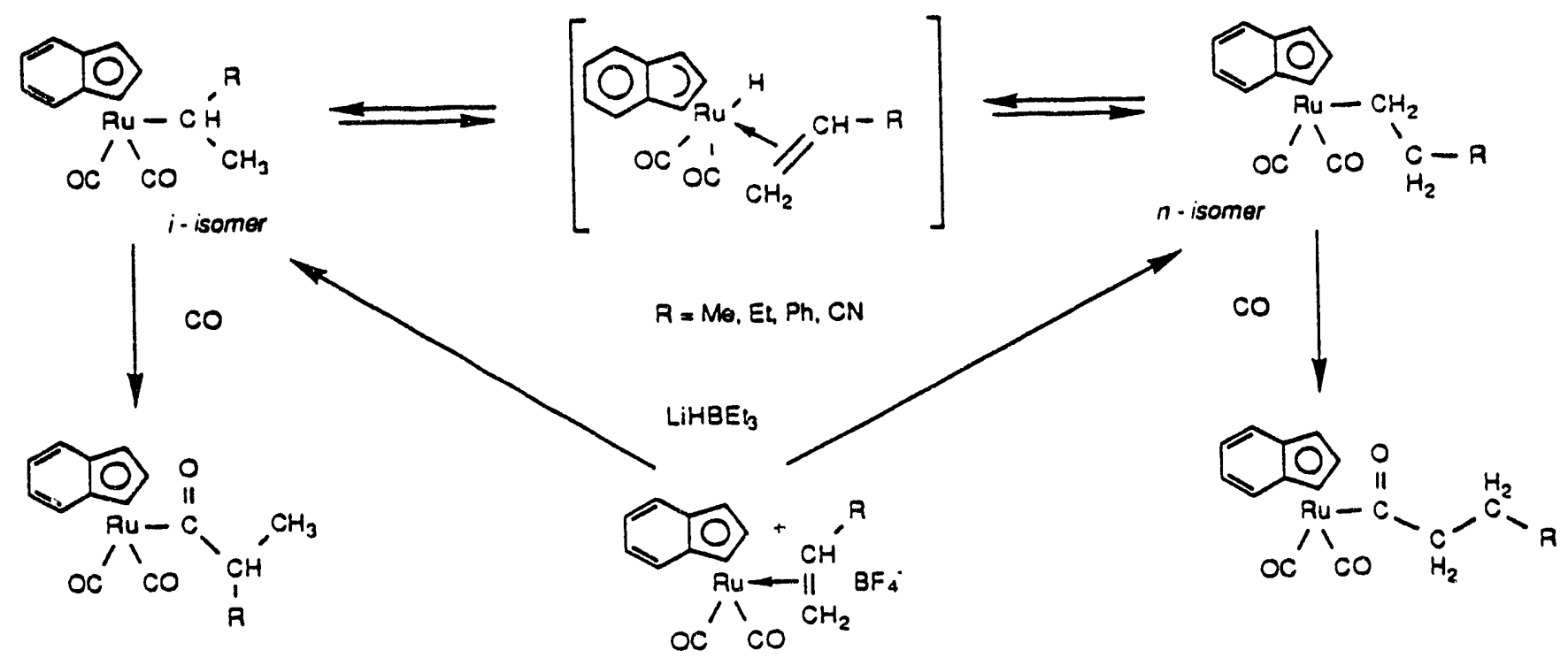

TIME AND EFFORT COMMITMENT TO PROJECT

The principal investigator has devoted approximctely $40 \%$ of his time during the academic year and $100 \%$ during two summer months on this project. It is anticipated that about the same time and effort commitment will be maintained during the remainder of the current term.

\section{PROPOSED STUDY}

Since this next year is the last year in this DOE grant. every effort will be made to consolidate the ongoing rescarch. Accordingly, rescarch plans for next year are noted in the Progress Report and in the Technical Scope document. 


\section{PUBLICATIONS}

\section{Appearing During Granting Period and Acknowledging DOE Support}

1. "Catalyzed and Noncatalyzed Hydrosilation of Organotransition Metal Acyl Complexes", P. K. Hanna, B. T. Gregg. D. L. Tarazano J. R. Pinkes, and A. R. Cutler, In Homogeneous Transition Metal Catalyzed Reactions; Advances in Chemistry 230; 1992, p. 491.

2. "Reactivity of Cobalt Acetyl Complexes $\left(\mathrm{PR}_{3}\right)(\mathrm{CO})_{3} \mathrm{CoCOCH}_{3}$ toward Monohydrosilanes", B. T. Gregg and A. R. Cutler, Organometallics 1992, 11, 4276.

3. "Synthesis and Solution D! ramics of $\left[\mathrm{Cp}(\mathrm{CO})_{2} \mathrm{Fe}\right]_{2}\left(\mathrm{CH}=\mathrm{CH}_{2}\right)+B F_{4}^{-}, a \mu-\left(\eta^{1}: \eta^{2}\right)$ Vinyl Complex Not Containing a Mctal-Metal Bond". D. L. Tarazano, T.W. Bodnar, and A. R. Cutler, J. Organomet. Chem. 1993, 448, 139.

4. "Synthesis and Carbonylation of Some $\alpha$-Alkoxyalkyl Cobalt Complexes, $\left[\mathrm{RCH}\left(\mathrm{OR}^{\prime}\right) \mathrm{Co}(\mathrm{CO})_{3} \mathrm{PPh}_{3}\right]\left(\mathrm{R}=\mathrm{H}, \mathrm{CH}_{3} ; \mathrm{R}^{\prime}=\mathrm{Me}, \mathrm{El}\right)$ ". C. C. Tso and A. R. Cutler, Polyhedron $1993,12,149$.

5. $" \mathrm{Mn}(\mathrm{CO})_{5} \mathrm{C}(\mathrm{O})-p-\mathrm{C}_{6} \mathrm{H}_{4} \mathrm{CH}_{3}$ - Catalyzed Monohydrosilane SiH/SiD Exchange: Evidence from a Kinetics Study Implicating Coordinatively Unsaturated Manganese Silyl Intermediatcs", B. T. Gregg and A. R. Cutler, Organometallics 1993, 12, 2006.

6. "Manganese Carbonyl Bromide-Catalyzed Alcoholysis of the Monohydrosilane HSiMe 2 Ph", B. T. Gregg and A. R. Cutler, Organometallics 1993, in press.

7. "Hydrosilation of Mianganese Acetyl $(\mathrm{CO})_{5} \cdot \mathrm{MnC}(\mathrm{O}) \mathrm{CH}_{3}$ With Monohydrosilancs". B. T. Gregg and A. R. Cutler, manuscript submitted.

8. "Transformation of Manganesc Acyls $(\mathrm{CO})_{5} \mathrm{MnC}(\mathrm{O}) \mathrm{CH}_{2} \mathrm{R}\left(\mathrm{R}=\mathrm{H}, \mathrm{CH}_{3}, \mathrm{OCH}_{3}\right)$ into their Siloxyvinyl Derivatives (CO) $)_{\text {MnC(OSiE(3) }=C H R}$ with Trichylsilane. An approach :O Double Carbonylation of Manganese Alkyl Complexes $\left(\mathrm{CO}_{5}, \mathrm{MnCH} \mathrm{CH}_{2} \mathrm{R}\right.$. B. T. Gregg and A. R. Cutler, manuscript submitted.

9. "Unusually Facile Carbonylation of $\left(\eta^{5}\right.$-Indenyl)ruthenium Wethyl and Methoxymethyl Complexes $\left(\eta^{5}-\mathrm{C}_{9} \mathrm{H}_{-}\right)\left(\mathrm{L}_{1}\right)\left(\mathrm{L}_{2}\right) \mathrm{R} u \mathrm{R}, \mathrm{L}_{1}, \mathrm{~L}_{2}=\mathrm{CO}$. PPh $\left.)^{\prime}\right)$. R. J. Chiulli. D. L. Tarazano, M. E. Dery. and A. R. Culler. manuseript to be submilted.

\section{Manuscripts in Preparation}

10. "Catalytic Hydrosilation of Iron Acyls $\mathrm{Cp}(\mathrm{CO})_{2} \mathrm{~F}=\mathrm{C}(\mathrm{O}) \mathrm{R}$ using Manganese Carbonyl 
Catalyst Precursors $(\mathrm{CO})_{5} \mathrm{MnY}(\mathrm{Y}=$ Alkyl, Acyl, Halide)", B. T. Gregg and A. R. Cutler.

11. "Carbonylation Driven Isomerization of ( $\eta^{5}$-Indenyl)ruthenium $\alpha$-Alkoxyethyl Complexes", R. J. Chıulli, D. L. Tarazano, and A. R. Cutler.

12. "Manganese- and Rhodium- Catalyzed Phenylsilane Hydrosilation - Reduction of Iron Acyl Complexes $\mathrm{Cp}(\mathrm{L})(\mathrm{CO}) \mathrm{FeC}(\mathrm{O}) \mathrm{R}\left(\mathrm{L}=\mathrm{CO}, \mathrm{PPh}_{3}, \mathrm{PE} t_{3}, \mathrm{P}(\mathrm{OMe})_{3}, \mathrm{P}(\mathrm{OPh})_{3} ; \mathrm{R}=\mathrm{CH}_{3}, \mathrm{Ph}\right.$, $\left.\mathrm{CMe}_{3}\right)^{\prime \prime}$, Z. Mao, B. T. Gregg, and A. R. Cutler.

13. "Diastereoselective Hydrosilation of Iron Acetyl Complexes $\mathrm{Cp}(\mathrm{L})(\mathrm{CO}) \mathrm{FeCOCH}_{3}(\mathrm{~L}=$ $\mathrm{PPh}_{3}, \mathrm{PE}$ t3 $\left._{3} \mathrm{P}(\mathrm{OMe})_{3}, \mathrm{P}(\mathrm{OPh})_{3}\right)$ using Rhodium Catalysis", J. R. Pinkes and A. R. Cutler.

14. "Organoiron Phosphido-Acelyl and - Methyl Complexes $\left(\eta^{5}-\mathrm{C}_{5} \mathrm{H}_{5}\right)(\mathrm{CO})\left(\mathrm{PPh}_{2}\right) \mathrm{Fe}-\mathrm{X}^{-}$ and $\left(\eta^{5}-\mathrm{C}_{9} \mathrm{H}_{7}\right)(\mathrm{CO})\left(\mathrm{PPh}_{2}\right) \mathrm{Fe}-\mathrm{X}^{-}\left(\mathrm{X}=\mathrm{COCH}_{3}\right.$ and $\left.\mathrm{CH}_{3}\right)$, their Synthesis,

Interconversion, and Reactions with Elcctrophiles", A. B. Todaro and A. R. Cutler.

I anticipate finishing and submitting the above 5 manuscripts by the end of the year. 

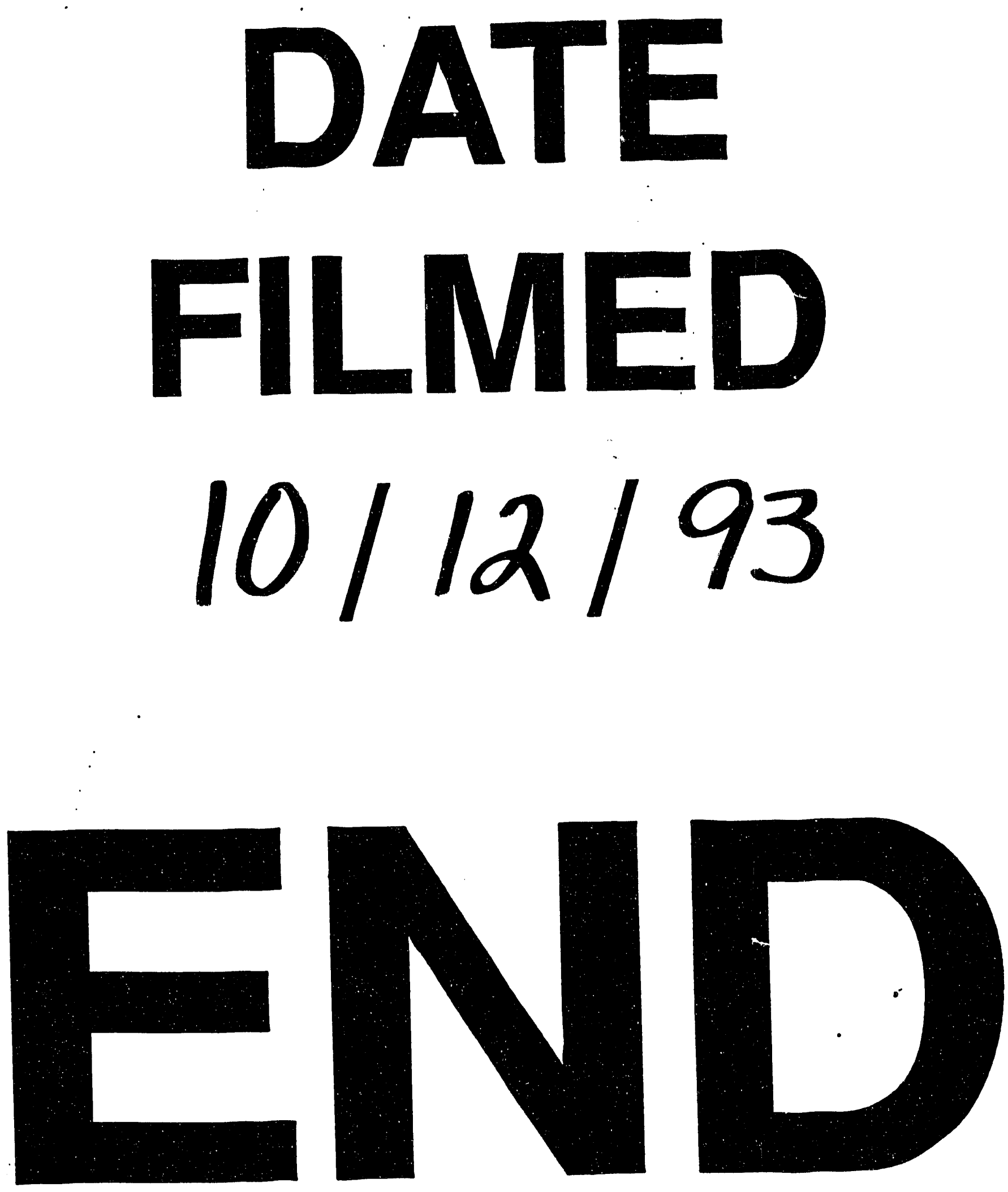
